\title{
GAME EDUKASI PENGENALAN HEWAN LANGKA BERBASIS ANDROID MENGGUNAKAN CONSTRUCT 2
}

\author{
Muhammad Fadil Akbar ${ }^{1}$, Damayanti*2 ${ }^{2}$ Heni Sulistiani ${ }^{3}$ \\ ${ }^{1}$ Informatika, Fakultas Teknik dan Ilmu Komputer, Universitas Teknokrat Indonesia \\ ${ }^{2}$ Sistem Informasi, Fakultas Teknik dan Ilmu Komputer, Universitas Teknokrat Indonesia \\ ${ }^{3}$ Informatika, Fakultas Teknik dan Ilmu Komputer, Universitas Teknokrat Indonesia \\ Email: ${ }^{1}$ azahra.fadil@gmail.com, ${ }^{2}$ damayanti@teknokrat.ac.id, ${ }^{3}$ henisulistiani@teknokrat.ac.id \\ *Penulis Korespindensi
}

(Naskah masuk: 19 Januari 2019, diterima untuk diterbitkan: 06 Februari 2018)

\begin{abstract}
Abstrak
Negara Indonesia memiliki kepulauan yang sangat luas dari daratan sampai pegunungan. Wilayah dalam kepulauan Indonesia terdapat flora dan fauna serta mikroba yang bermacam-macam. Habitat hewan di Indonesia mulai mengalami kepunahan, ini terjadi karena rusaknya habitat tempat tinggal hewan tersebut. Seiring dengan kepunahan hewan langka di Indonesia dan minimnya pengetahuan anak akan hewan-hewan langka khas daerah Indonesia serta kurangnya media pengenalan hewan langka. Maka penting dibuat game edukasi pengenalan hewan langka berbasis Android agar pengetahuan anak-anak dan masyarakat tentang hewan langka semakin meningkat. Penelitian ini menggunakan metode pengembangan sistem agile dan model UML (Unified Modelling Language). Tujuan dalam penelitian ini yaitu membangun sebuah game edukasi pengenalan hewan langka berbasis android yang memberikan edukasi sambil bermain dan dapat diakses melalui smartphone. Pembuatan game edukasi menggunakan construct 2 menjadi lebih mudah karena memiliki tools yang khusus dirancang untuk pembuatan game. Berdasarkan pengujian aplikasi game edukasi pengenalan hewan langka ini dapat membantu memperkenalkan hewan langka kepada masyarakat khususnya pada anak-anak, dengan perolehan presentasi penilaian pengujian sebesar $93,21 \%$.
\end{abstract}

Kata kunci: hewan langka, agile, construct2

\section{GAME EDUCATION INTRODUCTION OF RARE ANIMALS BASED ON ANDROID USING CONTRUCT 2}

\begin{abstract}
The country of Indonesia has very wide islands from land to mountains. Areas in the Indonesian archipelago have diverse flora and fauna and microbes. Animal habitats in Indonesia are beginning to become extinct, this occurs because of the destruction of the habitat where the animals live. Along with the extinction of rare animals in Indonesia and the lack of knowledge of children about rare animals typical of the Indonesian region and the lack of media for the introduction of rare animals. So it is important to make an Android-based rare animal recognition education game so that children's knowledge and society about endangered animals increases. This study uses the agile system development method and the UML (Unified Modeling Language) model. The purpose of this study is to build an educational game for the introduction of rare animals based on android that provides education while playing and can be accessed via a smartphone. Making educational games using construct 2 is easier because it has tools specifically designed for game creation. Based on the testing of this rare animal recognition educational game application, it can help introduce rare animals to the public, especially to children, with the acquisition of test rating presentations at $93.21 \%$.
\end{abstract}

Keywords: animal, agile, construct 2

\section{PENDAHULUAN}

Perkembangan teknologi saat ini sangat pesat, yang di tandai dengan penggunaan teknologi di berbagai bidang kehidupan, salah satunya dalam bidang pendidikan. Pemanfaatan teknologi informasi dan komunikasi dalam bidang pendidikan dapat memberikan solusi dan kemudahan dalam melakukan proses pembelajaran. Android merupakan salah satu teknologi informasi yang saat ini sedang berkembang. Android merupakan sistem operasi berbasis Linux yang dikembangkan oleh 
Open Handset Alliance terdiri dari software, hardware dan provider seperti Google, HTC, Intel, Motorola, Qualcomm, dan T-Mobile yang memiliki keunggulan adanya kelengkapan aplikasi-aplikasi yang tersedia dan kemudahan dalam menambahkan aplikasi sesuai keinginan pemakai (Rokhim, A. 2016). Pengguna Android Indonesia diketahui sebagai negara terbanyak di Asia yaitu mencapai 41 juta pengguna (Rachman, 2015). Pada umumnya penggunaan smarthone dikalangan remaja digunakan untuk bermain game (Muflih, Hamzah and Puniawan, 2017).

Indonesia merupakan negara kepulauan yang memiliki wilayah yang luas. Kepulauan Indonesia nterdiri dari daratan sampai pengunungan dimana didalammnya hidup flora dan fauna, serta mikroba yang beranekaragam (Triyono, 2013). Data dari Bappenas pada tahun 2003 menunjukkan bahwa terdapat 38.000 jenis tumbuhan atau $55 \%$ endemik. Sedangkan untuk jenis hewan bertulang belakang terdapat 515 jenis hewan yang menyusui atau $39 \%$ endemik. Selanjutnya 511 jenis reptilia atau 30\% endemik. Kemudian 1531 jenis burung atau 20\% endemik, serta terdapat 270 jenis amphibi atau $40 \%$ endemik.

Habitat hewan di Indonesia mulai mengalami kepunahan, ini terjadi karena rusaknya habitat tempat tinggal hewan tersebut. Seiring dengan kepunahan hewan langka di Indonesia dan minimnya pengetahuan anak akan hewan-hewan khas daerah Indonesia serta kurangnya media pengenalan hewan langka (Rokhim, A., 2016). Maka penting dibuat game edukasi pengenalan hewan langka berbasis Android menggunakan Construct 2 sehingga pengetahuan anak-anak dan masyarakat tentang hewan langka semakin meningkat. Android dipilih sebagai media game karena sebagian besar saat ini anak-anak dan masyarakat telah menggunakan android.

Game edukasi merupakan gabungan dari konten edukasi, prinsip pembelajaran, dan game komputer (Prensky, 2011). Game Edukasi merupakan salah satu jenis media yang digunakan untuk memberikan pengajaran, menambah pengetahuan penggunanya melalui suatu media unik dan menarik. Jenis ini biasanya ditujukan untuk anak-anak. Game edukasi yang dibangun menggunakan construct2. Construct2 merupakan game creator yang dibuat oleh Scirra yaitu salah satu game yang diminati para game developer karena construct2 yang mudah digunakan dan memiliki banyak tutorial serta template yang telah tersedia. Android merupakan salah satu device construct 2 menggunakan HTML5. Construct 2 dapat diunduh secara gratis dengan scene dan fitur terbatas sehingga membuat game menjadi tidak leluasa, namun berbeda dengan yang berlisensi memiliki scene dan fitur yang lebih banyak (Sholihin and Farouq, 2016). Metode pengembangan sistem yang digunakan adalah metode SDLC agile merupakan sekelompok metodologi pemrograman sentris yang berfokus pada penyederhanaan SDLC, sebuah metodologi yang digunakan untuk membuat stuktur, rencana dan kontrol pengerjaan suatu proyek. Sebagian besar overhead pemodelan dan dokumentasi dieliminasi. Sebuah proyek menekankan pengembangan aplikasi sederhana dan iteratif dimana setiap iterasi adalah proyek perangkat lunak yang lengkap, termasuk perencanaan, analisis kebutuhan, desain, pengkodean, pengujian dan dokumentasi (Dennis, Wixom and Roth, 2012).

Tujuan dalam penelitian ini yaitu membangun sebuah game edukasi pengenalan hewan langka berbasis Android yang memberikan edukasi sambil bermain dan dapat diakses melalui smartphone. Pembuatan game edukasi menggunakan construct 2 menjadi lebih mudah karena memiliki tools yang khusus dirancang untuk pembuatan game. Penelitian ini melanjutkan penelitian Rokhim, A., (2016), yaitu membuat game edukasi pengenalan hewan langka dengan fitur yang lebih lengkap dan interaktif (Rahayu, S., L dan Fujiati, 2018) sehingga meningkatkan minat anak-anak dan masyarakat dalam mengenal hewan-hewan langka. Game adukasi yang dibangun dapat menampilkan gambar dan suara hewan serta dapat belajar dan bermain puzzle serta kuis berbasis Android. Dimana pada penelitian terdahulu sebatas menampilkan gambar dan kuis saja. Untuk mendapatkan gambaran yang jelas tentang pembuatan game edukasi pengenalan hewan langka berbasis Android ini, maka batasan penelitian ini bahwa aplikasi yang dibuat menggunakan construct2, aplikasi game yang dibangun hanya dapat digunakan untuk pemain tunggal (single player), objek dari penelitian yaitu hewan langka khas pulau Sumatera dan Jawa.

\section{METODE PENELITIAN}

Penelitian harus dilakukan dengan perencanaan yang teratur dan sistematis untuk memujudkan tujuan. Tahapan penelitian pada penelitian ini menggunakan tahapan dengan model pengembangan sistem agile. Penelitian dilakukan dengan tahapantahapan pada gambar 2 .

\subsection{Planning}

Planning atau perencanaan pada penelitian meliputi metode pengumpulan data yang dilakukan untuk mendapatkan data dan keperluan lain dari penelitian. Metode pengumpulan data pada penelitian ini adalah:

\section{Tinjauan Pustaka (Literature Review)}

Metode pengumpulan data dilakukan dengan cara mempelajari berbagai laporan-laporan ilmiah, dokumen atau sumber bacaan, buku, dan jurnal yang relevan atau berhubungan dengan pembuatan aplikasi yang diusulkan. 
2. Wawancara

Wawacara dilakukan untuk mendapatkan informasi yang berkaitan dengan topic penelitian. Wawancara dilakukan kepada Kepala seksi Balai KSDA Bengkulu Seksi Konservasi Wilayah III Lampung.

3. Observasi

Observasi yang dilakukan oleh peneliti dilakukan di Balai KSDA Bengkulu Seksi Konservasi Wilayah III Lampung beralamat di Jl. ZA. Pagar Alam No. 1B Rajabasa Bandar Lampung.

\subsection{Analisis}

Tahap selanjutnya adalah tahap analisis yaitu mengidentifikasi permasalahan yang ada pada pengguna, dan mengidentifikasi solusi dari permasalahan pada komponen-komponen sistem. Menganalis kebutuhan sebagai bahan dalam membuat spesifikasi ditahapan selanjutnya. Analisis Menurut Sommerville (2011), analisis kebutuhan fungsional adalah analisis kebutuhan fungsi-fungsi yang harus ada pada sistem, bagaimana sistem harus berinteraksi terhadap masukan, dan berperilaku dalam menghasilkan output.

\subsection{Desain}

Tahap ketiga dalam penelitian ini yaitu melakukan pendesainan aplikasi game edukasi hewan langka berbasis Android. Desain sistem dan tampilan aplikasi dilakukan sebagai rancangan yang dapat menjadikan acuan dalam pembuatan aplikasi game edukasi pengenalan hewan langka berbasis Android menggunakan construct 2 .

\subsection{Implementasi Game Edukasi}

Tahap implementasi yaitu mengimplementasikan perancangan desain sistem kedalam situasi nyata. Desain sistem yang telah dirancang akan diimplementasikan kedalam tools pembuatan game menggunakan construct 2 yaitu dengan tools Construct 2 versi 2.244 .

\subsection{Rencana Pengujian}

Pengujian dilakukan untuk memastikan apakah aplikasi dapat berjalan baik pada lingkungan sistem oprasi dari user. Pengujian alpha ini dilakukan oleh pengembang aplikasi sendiri dengan cara menjalankan aplikasi pada perangkat android versi Lollipop. Pengujian aplikasi ini menggunakan pengujian black-box. Pengujian black-box merupakan pengujian fungsionalitas kemampuan perangkat lunak untuk menyediakan fungsi sesuai kebutuhan pengguna ketika digunakan dalam kondisi tertentu dengan tidak menguji kode program.

\section{PERANCANGAN SISTEM}

Pada sistem aplikasi game edukasi pengenalan hewan langka berbasis Android menggunakan construct2, dan perancangan Unified Modelling Language yaitu:

\subsection{Use Case Diagram}

Use case diagram adalah diagram yang mendeskripsikan interaksi antar pengguna dengan sistem aplikasi. Fungsionalitas pada sistem digambarkan dengan menggunakan use case diagram Desain use case pada penelitian ini ditujukkan pada gambar 4.

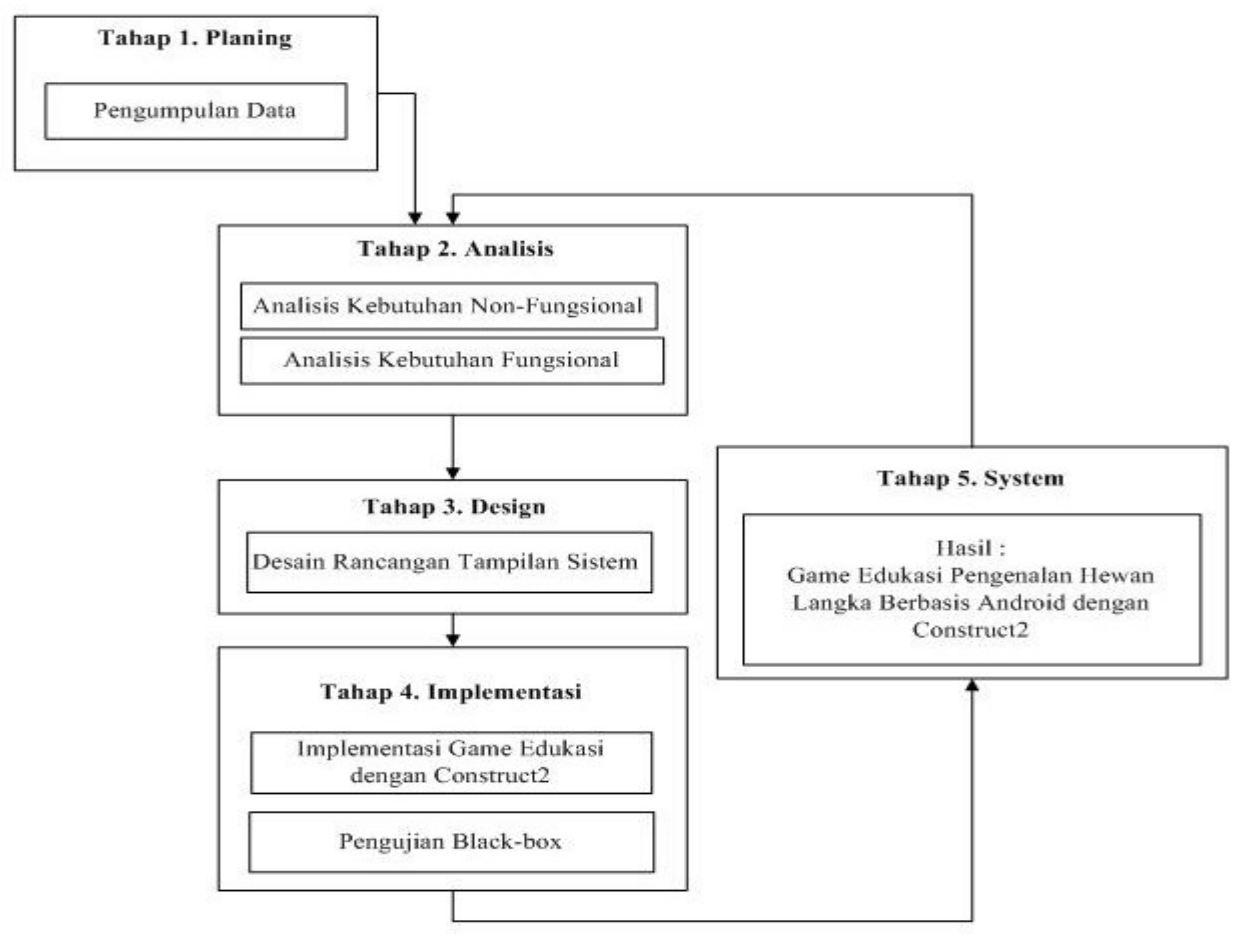




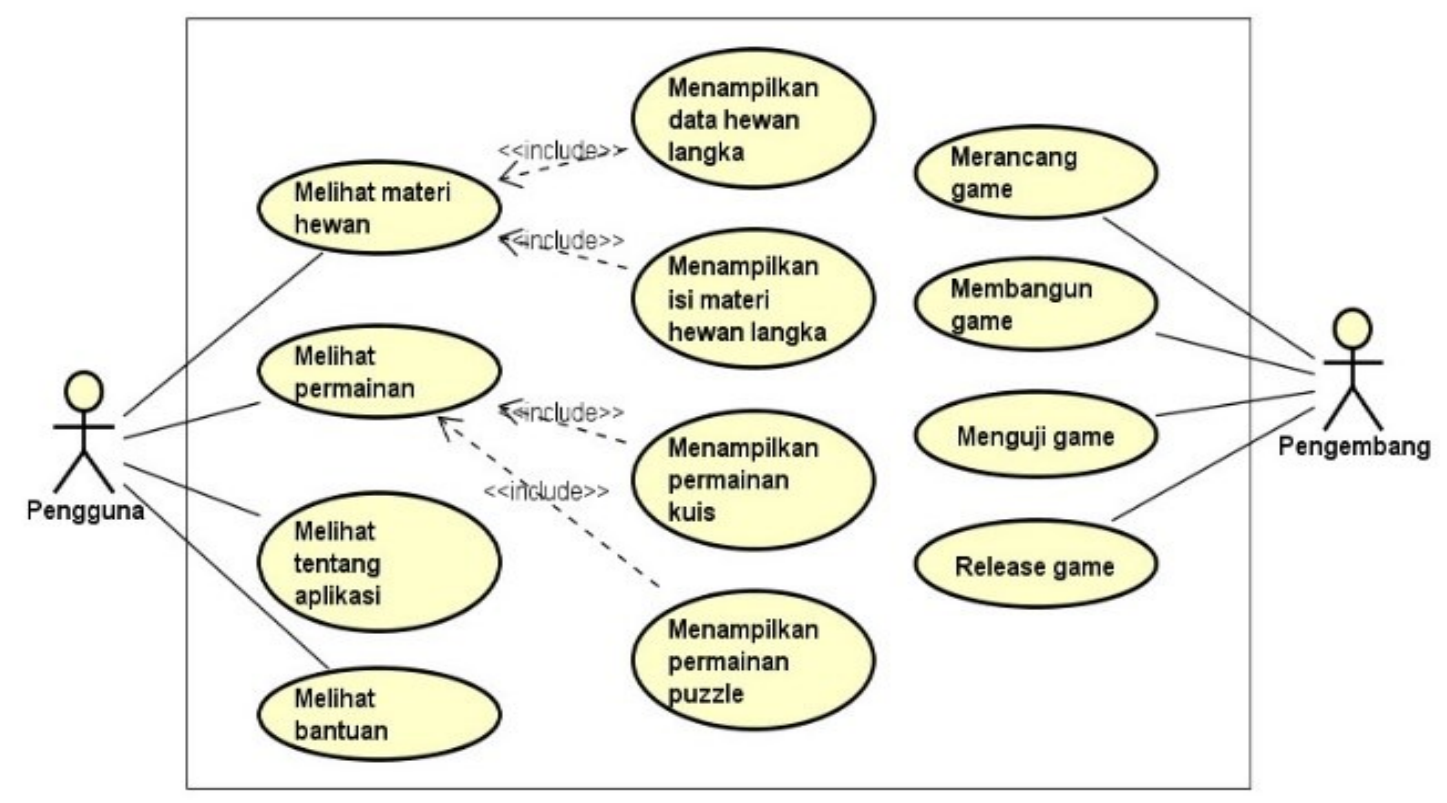

Gambar 4. Use Case Diagram

Keterangan:

1. Pengguna dapat memilih menu materi hewan. Pada menu materi hewan terdiri dari data hewan dan materi pembahasan hewan langka.

2. Pengguna dapat memilih menu permainan, dimana dalam menu permainan pengguna dapat melakukan kuis menebak nama hewan dan juga melakukan game puzzle.

3. Pengguna dapat memilih menu tentang aplikasi yang berisi informasi aplikasi game edukasi pengenalan hewan langka.

4. Pengguna dapat memilih menu bantuan, yang berisi bantuan penggunaan aplikasi.

\subsection{Activity Diagram}

Activity Diagram menggambarkan workflow (aliran kerja) atau aktivitas proses dari sebuah sistem. Activity diagram pada rancangan aplikasi ini dapat dilihat pada gambar 5 .

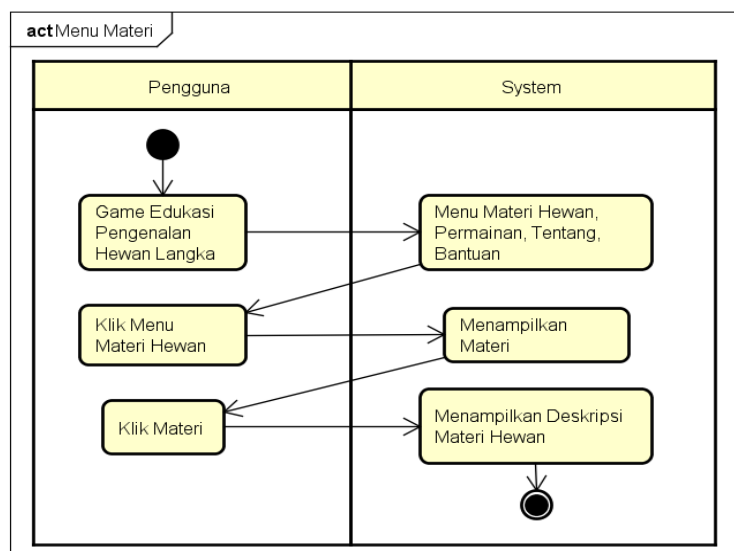

Gambar 5. Activity Diagram Menu Materi

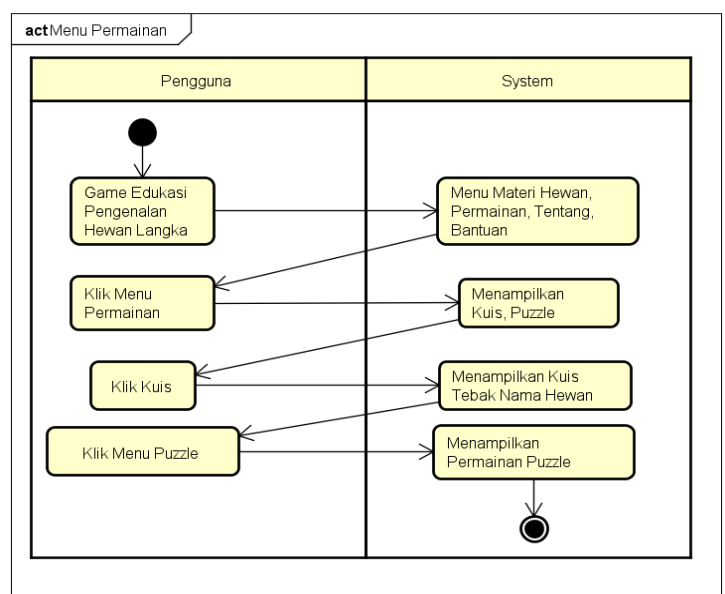

Gambar 6. Activity Diagram Menu Permainan

\subsection{Rancangan Tampilan Sistem}

Perancangan struktur navigasi yang menggambarkan hubungan antar menu pada aplikasi game edukasi pengenalan hewan langka ini menggunakan model hirarki. Perancangan navigasi pada aplikasi game edukasi ini nampak pada gambar 7.

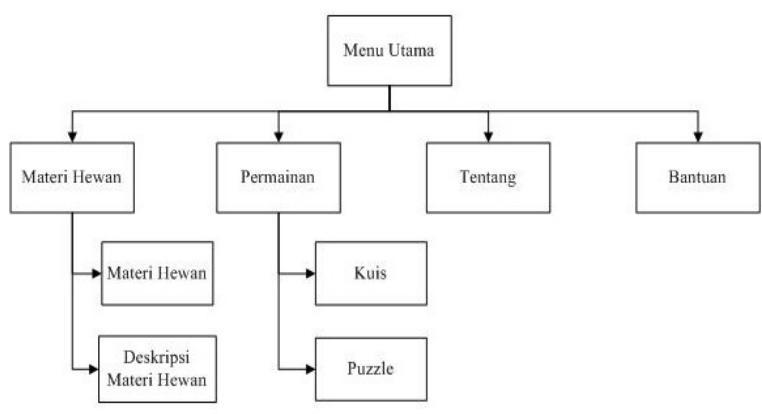

Gambar 7. Struktur Navigasi Aplikasi

Perancangan Story Board merupakan rancangan interface atau tampilan antar muka dari aplikasi 
yang dilengkapi spesifikasi dari setiap gambar, layer dan teks. Gambaran story board game edukasi lihat pemaparan gambar 8 .

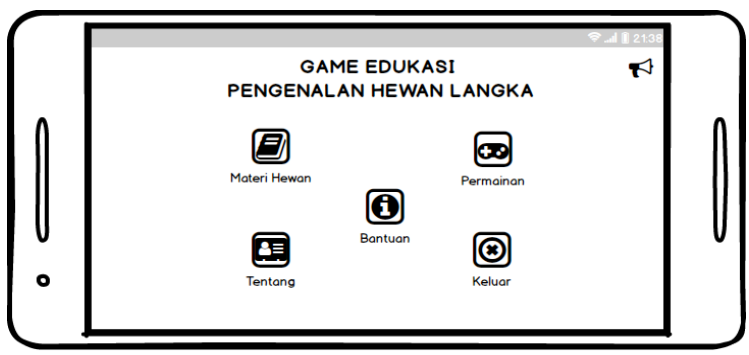

Gambar 8. Story Board Menu Utama

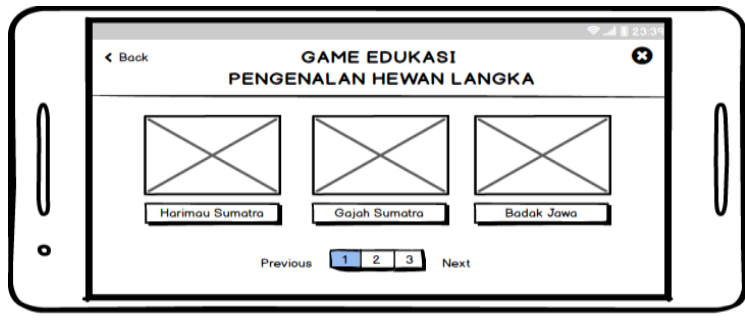

Gambar 9. Story Board Menu Materi Hewan

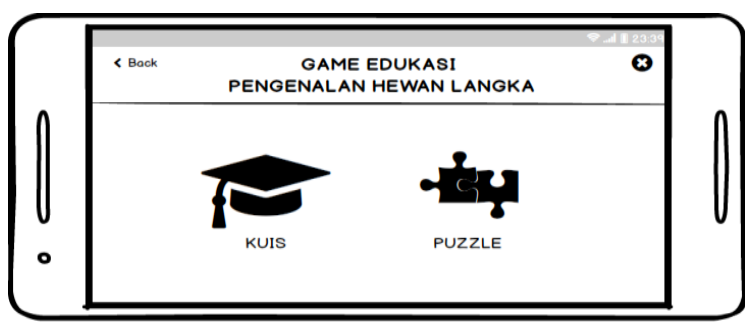

Gambar 10. Story Board Menu Permainan

\section{HASIL DAN PEMBAHASAN}

Penelitian ini telah menghasilkan sebuah aplikasi game edukasi pengenalan hewan langka berbasis Android menggunakan Construct2. Pembuatan game edukasi pengenalan hewan langka ini bertujuan untuk memperkenalkan hewan langka, dan membuat aplikasi yang dapat menampilkan gambar, suara disertai permainan puzzle dan kuis berupa tebak nama hewan.

\section{I Implementasi Program}

Implementasi game edukasi terhadap pengenalan hewan langka berdasarkan rancangan sistem dan desain kedalam tools Construct2 adalah sebagai berikut:

\section{Menu Loading Screen}

Menu loading screen ini adalah tampilan awal saat akan membuka aplikasi game pengenalan hewan langka.

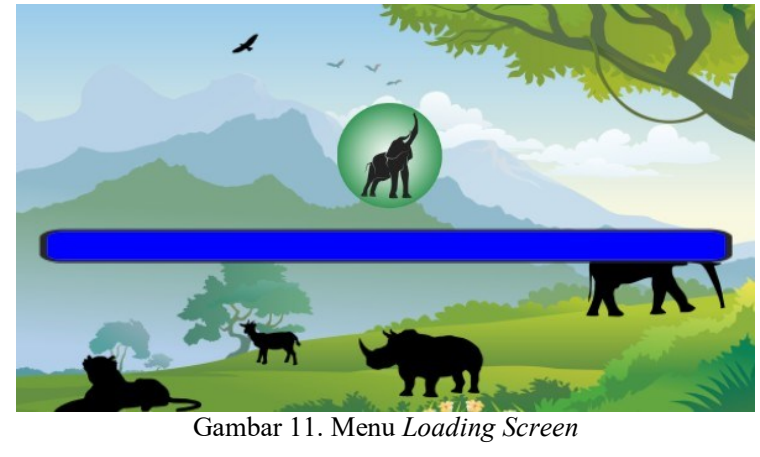

\section{Menu Utama}

Menu utama merupakan menu tampilan utama saat telah masuk kedalam aplikasi. Pada menu utama terdapat beberapa menu lainnya yaitu, menu materi, permainan, tentang, bantuan dan menu keluar aplikasi.

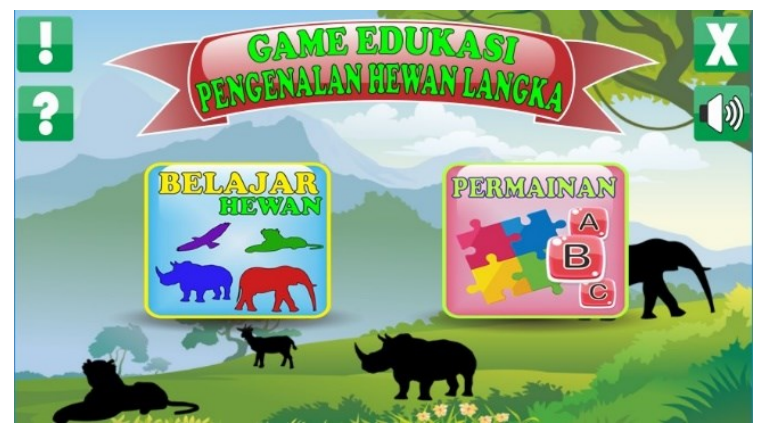

Gambar 12. Menu Utama

\section{Menu Materi Hewan}

Menu materi hewan merupakan menu yang memberikan materi-materi hewan langka. Pada menu materi terdapat beberapa materi hewan yang dapat dilihat dari gambar hewan dan nama hewan.

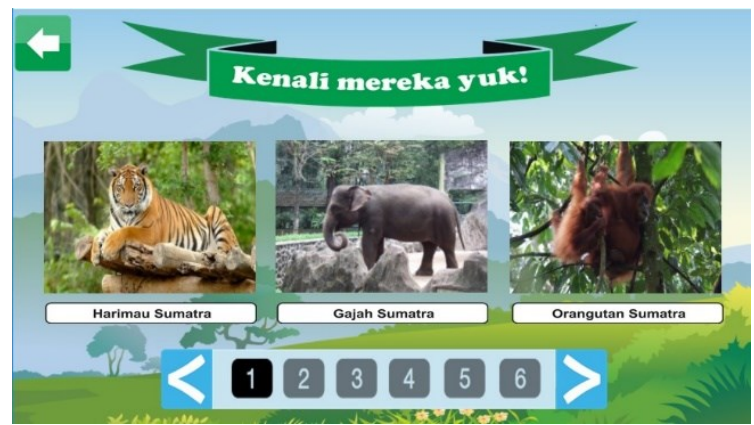

Gambar 13. Menu Materi Hewan

\section{Menu Isi Materi Hewan}

Menu isi materi merupakan menu lanjutan dari menu materi, setelah memilih salah satu materi hewan langka, maka akan menampilkan menu isi materi hewan langka. Pada menu ini berisi materi ciri-ciri hewan, habitat tinggal hewan, makanan hewan dan suara hewan. 


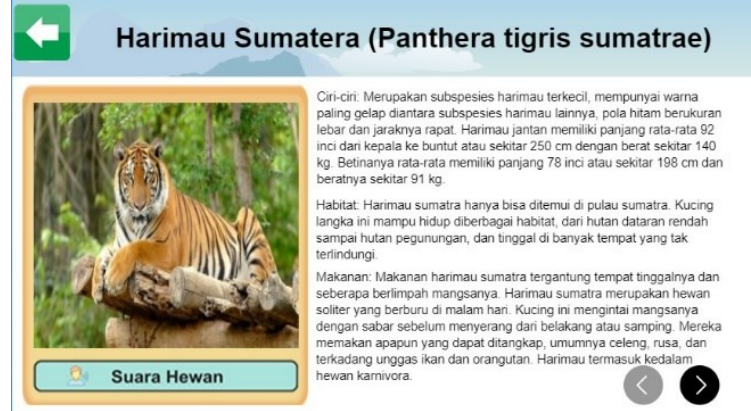

Gambar 14. Menu Isi Materi Hewan

\section{Menu Permainan}

Menu permainan adalah menu permainan yang terdiri dari menu perminan kuis berupa tebak nama hewan dan permainan puzzle.

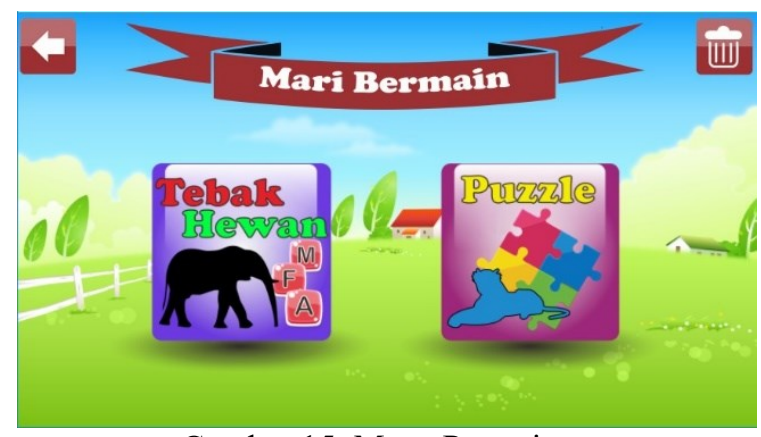

Gambar 15. Menu Permainan

\section{Menu Permainan Tebak Hewan}

Menu permainan tebak hewan ini merupakan menu tebak hewan permainan dengan menyusun kata nama hewan.

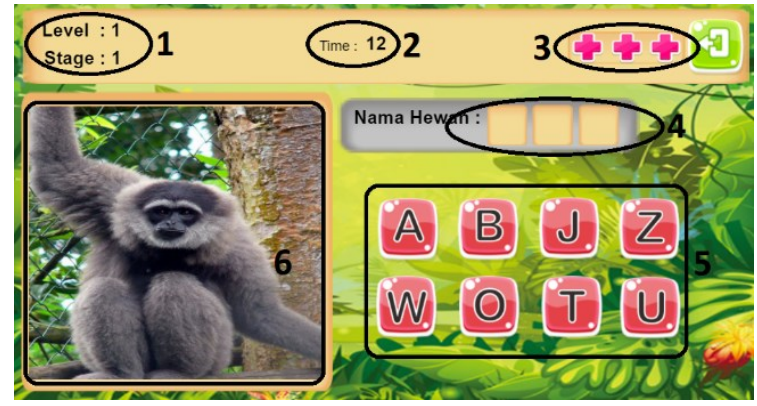

Gambar 16. Menu Permainan Tebak Hewan

Keterangan:

1. Menunjukan pemain berada pada level 1 dan stage 1 .

2. Menunjukan siswa waktu bermain pada stage tersebut.

3. Menunjukan jumlah nyawa atau kesempatan salah dalam menebak huruf nama hewan.

4. Menunjukan jumlah huruf yang harus ditebak.

5. Menunjukan pilihan huruf yang harus dipilih.

6. Menunjukan gambar hewan yang harus ditebak namanya.

\section{Menu Permainan Puzzle}

Menu permainan puzzle merupakan menu permainan susun gambar hingga membentuk hewan langka.

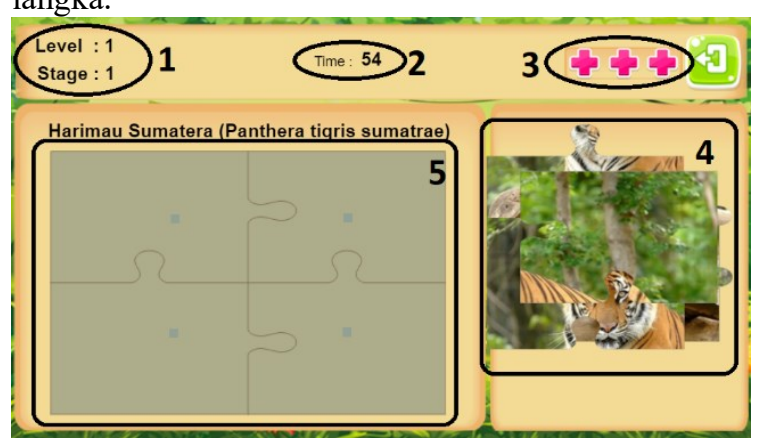

Gambar 17. Menu Permainan Puzzle

Keterangan:

1. Menunjukan pemain berada pada level 1 dan stage 1.

2. Menunjukan siswa waktu bermain pada stage tersebut.

3. Menunjukan jumlah nyawa atau kesempatan dalam menyusun gambar.

4. Menunjukan potongan gambar yang harus disusun.

5. Menunjukan tempat dimana pemain melakukan drop pada potongan gambar.

\subsection{Hasil Pengujian Black-Box}

Pengujian black-box mencakup pengujian fungsionalitas kemampuan perangkat lunak untuk menyediakan fungsi sesuai kebutuhan pengguna ketika digunakan dalam kondisi tertentu dengan tidak menguji kode program. Pada pengujian ini kuesioner diisi oleh orang yang ahli dalam software engenering untuk mengetahui apakah fungsi-fungsi pada sistem dapat berjalan dengan benar (sukses atau gagal).

\subsection{Hasil Pengujian Pengguna}

Pengujian sistem dilakukan terhadap siswa kelas 5 Sekolah Dasar. Dalam pengujian ini terdapat 22 orang responden. Pengujian dilakukan dengan cara seluruh responden mencoba aplikasi game edukasi pengenalan hewan langka, kemudian mengisi kuesioner pengujian yang diberikan oleh peneliti. Jumlah pertanyaan dalam kuesioner terdiri dari 13 pertanyaan dengan skala skor nilai yaitu Sangat Tidak Setuju (STS) $=1$, Tidak Setuju (TS) $=$ 2 , Netral $(N)=3$, Setuju $(S)=4$, Sangat Setuju (SS) $=5$. Hasil pengujian untuk pengguna ini dapat dilihat pada tabel 2 . 
Tabel 1. Hasil Pengujian Black-Box

\begin{tabular}{|c|c|c|}
\hline No. & Fungsi & Hasil \\
\hline 1 & $\begin{array}{l}\text { Menampilkan } \\
\text { halaman pembukaan } \\
\text { dengan gambar dan } \\
\text { musik }\end{array}$ & Oke \\
\hline 2 & $\begin{array}{l}\text { Menampilkan menu } \\
\text { utama }\end{array}$ & Oke \\
\hline 3 & $\begin{array}{l}\text { Menampilkan } \\
\text { Menu materi hewan } \\
\text { langka }\end{array}$ & Oke \\
\hline 4 & $\begin{array}{l}\text { Menampilkan } \\
\text { Menu isi materi } \\
\text { hewan langka }\end{array}$ & Oke \\
\hline 5 & $\begin{array}{l}\text { Menampilkan menu } \\
\text { permainan } \\
\text { Menampilkan menu } \\
\text { permainan tebak } \\
\text { hewan }\end{array}$ & Oke \\
\hline 6 & $\begin{array}{l}\text { Menampilkan menu } \\
\text { permainan tebak } \\
\text { hewan level }\end{array}$ & Oke \\
\hline 7 & $\begin{array}{l}\text { Menampilkan menu } \\
\text { game tebak hewan }\end{array}$ & Oke \\
\hline 8 & $\begin{array}{l}\text { Menampilkan menu } \\
\text { reward permainan } \\
\text { tebak hewan }\end{array}$ & Oke \\
\hline 9 & $\begin{array}{l}\text { Menampilkan menu } \\
\text { permainan puzzle }\end{array}$ & Oke \\
\hline 10 & $\begin{array}{l}\text { Menampilkan } \\
\text { permainan puzzle }\end{array}$ & Oke \\
\hline 11 & $\begin{array}{l}\text { Menampilkan menu } \\
\text { bantuan }\end{array}$ & Oke \\
\hline 12 & $\begin{array}{l}\text { Menempilkan menu } \\
\text { tentang }\end{array}$ & Oke \\
\hline 13 & $\begin{array}{l}\text { Menekan tombol } \\
\text { keluar aplikasi }\end{array}$ & Oke \\
\hline
\end{tabular}

Perhitungan skor berdasarkan kriteria penilaian dan kategori penilaian diperoleh dari:

Skor Hasil Pengujian =

Jumlah Responden x Bobot Nilai (per kategori)

Persentase $=$

(Skor Hasil Pengujian $\div$ Skor Tertinggi) x $100 \%$

Berikut merupakan hasil perhitungan skor per 5

kriteria penilaian dari 22 responden yaitu :

Skor Hasil Pengujian :

$=(199 \times 5)+(77 \times 4)+(10 \times 3)$

$=995+308+30$

$=1333$

Skor Tertinggi :

$=13$ (jumlah pertanyaan) $\times 5 \times 22$ (responden)

$=1430$

Presentase :

$=($ Skor Hasil Pengujian $) /($ Skor Tertinggi) $\times 100 \%$

$=1333 / 1430 \times 100 \%$

$=93,21 \%$

Berdasarkan hasil perhitungan presentase pengujian yang dilakukan kepengguna anak-anak, dengan nilai presentase sebesar 93,21\% dapat disimpulkan bahwa pengguna sangat puas dengan aplikasi game edukasi pengenalan hewan langka.
Tabel 2. Hasil Pengujian Pengguna

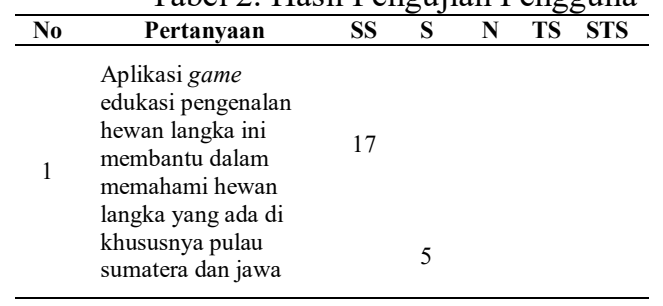

Aplikasi game

edukasi pengenalan

hewan langka ini

2 dapat membantu 20

dalam menambah

atau meningkatkan

wawasan tentang

hewan langka

\begin{tabular}{|c|c|c|c|}
\hline 3 & $\begin{array}{l}\text { Aplikasi game } \\
\text { edukasi pengenalan } \\
\text { hewan langka ini } \\
\text { membantu untuk } \\
\text { lebih mengenali } \\
\text { hewan langka }\end{array}$ & 15 & \\
\hline & $\begin{array}{l}\text { Cara menggunakan } \\
\text { aplikasi game } \\
\text { edukasi sangat } \\
\text { sederhana }\end{array}$ & 15 & 7 \\
\hline
\end{tabular}

\begin{tabular}{lllll}
\hline 4 & $\begin{array}{l}\text { Saya belajar untuk } \\
\text { menggunakan } \\
\text { aplikasi ini dengan } \\
\text { cepat }\end{array}$ & 12 & 7 & \\
\hline $\begin{array}{l}\text { Cara penggunaan } \\
\text { aplikasi game }\end{array}$ & & 7 & 3 \\
\hline
\end{tabular}

5 edukasi pengenalan 7

hewan langka sangat

mudah

Saya menggunakan 15

aplikasi game

6 edukasi ini tanpa $\quad 17$

bantuan (mudah

dimengerti)

\begin{tabular}{lll} 
dimengerti) & & \\
\hline Aplikasi merespon & 3 & 2
\end{tabular}

7 dengan baik 15

\begin{tabular}{lllll}
\hline 8 & $\begin{array}{l}\text { Aplikasi merespon } \\
\text { dengan baik }\end{array}$ & 14 & 7 & 1 \\
\hline 9 & $\begin{array}{l}\text { Tampilan pada } \\
\text { aplikasi menarik }\end{array}$ & 14 & 3 & 1 \\
\hline & Game edukasi yang & 3 & 3
\end{tabular}

10 diberikan menarik 16

Kesesuaian gambar $\quad 11$

11 dengan background 19

Kesesuaian tulisan 11

$12 \quad \begin{aligned} & \text { Kesesuaian tulisan } \\ & \text { dengan background }\end{aligned}$ baik

Secara keseluruhan

saya puas dengan

3 aplikasi game 22

edukasi pengenalan

hewan langka

Total

$199 \quad 77 \quad 10$

\section{KESIMPULAN DAN SARAN}

5.1. Kesimpulan

Berdasarkan penelitian dan pembahasan, yang telah dilakukan disimpulkan bahwa:

1. Game edukasi yang telah dibuat dapat menampilkan gambar dilakukan dengan menambahkan evensheet sprite pada layout construct2, menampilkan suara, membuat puzzle dilakukan dengan cara memecah gambar menjadi beberapa bagian sesuai dengan jumlah potongan 
pada setiap level. Potongan-potongan tersebut dipanggil dengan event sprite dengan menambahkan frame animation sebagai animasinya. Pembuatan permainan kuis dilakukan dengan cara memasukan gambar yang akan ditebak namanya, kemudian mamasukan huruf-huruf yang akan menjadi pilihan kata pada permainan kuis. Penambahan keterangan time atau waktu bermain dan jumlah nyawa dimasukan dengan even sprite frame animation.

2. Berdasarkan hasil pengujian yang telah dilakukan ke pengguna aplikasi game edukasi pengenalan hewan langka, dimana sasaran utamanya adalah anak-anak kelas 5 SD, dapat disimpulkan bahwa game edukasi ini dapat membantu dalam memperkenalkan hewan langka. Pengujian yang dilakukan memperoleh nilai presentase sebesar 93,21\%, hasil presentase ini menunjukkan bahwa sasaran utama pembuatan game ini memiliki kepuasan dalam menggunakan aplikasi game edukasi pengenalan hewan langka.

\subsection{Saran}

Berkaitan dengan penelitian ini, maka saran yang perlu diperhatikan dalam mengembangkan aplikasi ini selanjutnya yaitu :

1. Jenis hewan yang digunakan lebih banyak dan lengkap serta menambahkan animasi hewan.

2. Menambah level permainan sehingga lebih banyak tantangan dalam bermain game.

\section{DAFTAR PUSTAKA}

A.S., R. \& SHALAHUDIN, M., 2015, Rekayasa Perangkat Lunak. Bandung: Informatika Bandung.

ADAM, E. \& ROLLING, A., 2003, Andrew Rollings and Ernest Adams On Game Design. New Riders.

AGUSTINA, C. \& WAHYUDI, T., 2015, 'Aplikasi Game Pendidikan Berbasis Android Untuk Memperkenalkan Pakaian Adat Indonesia', Indonesian Journal on Software Engineering, 1(1).

ARGOMEDI, R., 2008, Merawat Hewan Kesayangan. Tanggerang: PT Argomedia Pustaka.

COSTIKYAN, G., 2013, Uncertainty in Games. Edited by J. Juul, G. Long, and W. Uricchio. America: The MIT Press.

DENNIS, A., \& DKK, 2012, System Analysis \& Design. 5th edn. Edited by B. L. Golub. America: Don Fowlley.

GUNAWAN, F., 2015, 'Aplikasi Game Petualangan bagi Anak-Anak sebagai Media Pembelajaran Flora dan Fauna di Indonesia Fendik', J-Intech, 3(1).
HANDRIYANTINI, E., 2009, 'Permainan Edukatif (Educational Games) Berbasis Komputer untuk Siswa Sekolah Dasar'.

MUFLIH, M., \& DKK, 2017, 'Penggunaan Smartphone dan Interaksi Sosial pada Remaja di SMA Negeri 1 Kalasan Sleman Yogyakarta', Idea Nursing Journal, 8(1).

MURTIWIYATI \& LAUREN, G., 2013, 'Rancang Bangun Aplikasi Pembelajaran Budaya Indonesia Untuk Anak Sekolah Dasar berbasis Android', Jurnal Ilmiah KOMPUTASI, 12(2).

NOTOATMODJA, S., 2003, Pendidikan dan Perilaku Kesehatan. Jakarta: Rineka Cipta.

RAHAYU, S.L., dan FUJIATI, 2018, Penerapan Game Design Document Dalam Perancangan Game Edukasi yang Interaktif untuk Menarik minat Siswa dalam Belajar Bahasa Inggris, Jurnal Teknologi Informasi dan Ilmu Komputer, Vol 5, No. 5, 341-346

PRENSKY, M., 2011, 'From Digital Natives to Digital Wisdom', From Digital Natives to Digital Wisdom, pp. 1-9. doi: http://dx.doi.org/10.4135/9781483387765.

RACHMAN, A. F., 2015, 'Android Kuasai Asia Tenggara. Dipetik January 24, 2018, dari https://inet.detik.com/consumer/d3054169/a ndroid-kuasai-asia-tenggaradi-indonesiapaling-juara'.

ROKHIM, A., 2016, 'Rancang Bangun Aplikasi Pengenalan Hewan Berbasis Suara pada Sistem Operasi Android', Jurnal Insand Comtech, 1(2).

SHOLOIHIN, M. \& FAROUQ, K., 2016, 'Game Pass-Puzz dengan Construct 2', JouticaPress.

SOMMERVILLE, I., 2011, SoftwareEngineering. Ninth Edit. America: Addison-Wesley.

SUGIANTO, Y. \& MARTONO, 2015, 'Perancangan Game Edukasi Pengenalan Binatang Dan Habitatnya Berbasis Android ( Studi Kasus: Tk Ar Ridho Kel . Eka Jaya Jambi )', Jurnal Ilmiah Media Processor, $10(1)$.

TRIYONO, K., 2013, 'Keanekaragaman hayati dalam menunjang ketahanan pangan', INNOFARM: Jurnal Inovasi Pertanian, 11(1).

WILEY, J., 2014, Gaming Development Fundamentals. Edited by B. Gambrel. America: Don Fowley. 